\title{
ENSURING SMART, SUSTAINABLE, INCLUSIVE DEVELOPMENT OF THE REGIONS OF UKRAINE IN THE CONDITIONS OF STRUCTURAL CRISIS
}

\author{
Tetiana BOGOLIB ${ }^{1}$ \\ Pereiaslav-Khmelnitskyi State Pedagogical University named after Hryhorii Skovoroda, Ukraine
}

\begin{abstract}
The formation of the economy based on knowledge-based innovative economy, new economy, at the present stage of social development is defining the international concept, according to which knowledge play a primary role, and their production is a source of economic growth and competitiveness. The economy is based on knowledge that provides a smart, sustainable and inclusive development. The purpose of the study. Showing that the implementation of the Strategy «Europe 2020», the main directions of the Fourth Industrial Revolution in the Ukraine will be able to provide smart, sustainable, inclusive development of the regions of Ukraine, will help to overcome the crisis and become a source for economic growth. Research methods. In the process of writing were used scientific methods, methods of analysis and synthesis, method of scientific abstraction. The results of the study. Macroeconomic instability has been transformed at the regional level, which led to the deepening of regions differentiation, particularly as it affected old industrial regions, including Donetsk and Luhansk. The crisis of public finances does not allow attracting of financial resources for economic development. As a result of hybrid war, the outflow of foreign investment amounted to 12.6 billion dollars USA. A significant part of the Donetsk and Luhansk regions is completely destroyed. Along with this, it's perfect conditions in order to abandon the old and build new. There are all conditions to implement actively the European strategy «Europe 2020» and the main directions of the Fourth Industrial Revolution to a new stage of economic development, and ensure smart, sustainable and inclusive development of the regions of Ukraine. Conclusions and discussion position. The future of Ukraine and its regions depends on the activity of the Strategy «Europe 2020» and the main directions of the Fourth Industrial Revolution. In Ukraine, in the regions, the main emphasis is on export-oriented industries: coal, metallurgical, chemical, machine-building industry. Technically they are 3 and 4 technological structures, so they cannot become the breakthrough sectors of the Ukrainian economy, so the main emphasis should be on smart, sustainable and inclusive development.
\end{abstract}

Key words: smart growth, sustainable development, inclusive growth, differentiation of regions, the Fourth Industrial Revolution.

JEL Classification: O40, O18, R19

\section{Introduction}

Current process of regions' development is based on the peculiar to it auto-poetic sub-integrity of self-organization mechanisms. At the same time the state should become a guarantor of forced development of national ICTproduction, a catalyst of accelerated establishment of prior clusters of new economic production on the basis of wide use of instruments of state-private partnership, introduction of effective redistribution of new economic over-rent from consumers for the good of national producers based on the use of corresponding fiscal measures.

Scientific novelty. The scientific article determines main constituents of further development of regions of Ukraine that are based on the smart, sustainable, inclusive development with wide use of IT technologies, and as a result, creation of Smart Homes, Smart Cities and overcoming of regions development differentiation.

Actuality of scientific solutions lies in necessity of Ukrainian economy's overcoming the crisis and regions' differentiation. Ukraine has no financial resources to develop resource economy, an economic break should be made; those countries ensure their successful development that staked on knowledge economy.

For Ukraine the only smart move is ensuring of smart, sustainable, inclusive development.

Forming of economy, which is based on knowledge (innovative economy, new economy), at the present stage of social development is a determinative international

Corresponding author:

${ }^{1}$ Finance-Humanitarian Faculty, Pereiaslav-Khmelnitskyi State Pedagogical University named after Hryhorii Skovoroda.

E-mail: bogolib60@mail.ru 
concept, according to which knowledge play the leading role and their production is a source for economic development and competitiveness. Economy based on knowledge guarantees the smart, sustainable and inclusive development.

The purpose of the research. Showing that realization of the Strategy "Europe 2020", main directions of the Fourth Industrial Revolution in the Ukraine will be able to provide smart, sustainable, inclusive development of the regions of Ukraine, will help to overcome the crisis and become a source for economic growth.

Methodology of researches is determined by works of Ukrainian and foreign scientists, statistical data of the State Statistics Service of Ukraine and the EU, legal documents and scientific articles.

In the process of writing were used scientific methods, methods of analysis and synthesis, method of scientific abstraction.

Scientific results. Macroeconomic instability has been transformed at the regional level, which led to the deepening of regions differentiation, particularly as it affected old industrial regions, including Donetsk and Luhansk. The crisis of public finances does not allow attracting of financial resources for economic development. As a result of hybrid war, the outflow of foreign investment amounted to 12.6 billion dollars USA. A significant part of the Donetsk and Luhansk regions is completely destroyed. Along with this, it's perfect conditions in order to abandon the old and build new. There are all conditions to implement actively the European strategy «Europe 2020» and the main directions of the Fourth Industrial Revolution to a new stage of economic development, and ensure smart, sustainable and inclusive development of the regions of Ukraine.

Conclusions and discussion position. The future of Ukraine and its regions depends on the activity of the Strategy «Europe 2020» and the main directions of the Fourth Industrial Revolution. In Ukraine, in the regions, the main emphasis is on export-oriented industries: coal, metallurgical, chemical, machine-building industry. Technically they are 3 and 4 technological structures, so they cannot become the breakthrough sectors of the Ukrainian economy, so the main emphasis should be on smart, sustainable and inclusive development.

\section{Development of Ukraine in terms of new economy}

Modern society is a scene for deep, diversified transformation. An important role in modern society belongs to the new economy, which is based on knowledge. Not coal, oil, metal are the main wealth of countries, but knowledge, education and scientific discoveries. Those countries forge ahead that had staked on science and education. Countries, with stake on rawmaterials branches, are significantly falling in development behind others and often becoming crisis areas. In terms of globalization the new economy is becoming an integral part of national economies of highly-developed countries, ensuring a sustainable development and competitiveness. Modern world made a step toward the Fourth Industrial Revolution and modern Europe successfully implements the Strategy "Europe 2020", which are based on smart, sustainable and inclusive development.

Ukraine today is at the cross-roads, all depends on the choice, which will be made; we consider that Ukraine and its regions can develop successfully if refusing the old and taking a step towards the new: the Strategy "Europe 2020" and the Fourth Industrial Revolution. Problems of the new economy's essence determination, ensuring of smart, sustainable and inclusive development, their role in economic dynamics, scientific and technological foundations of challenges facing humanity stipulate a stepping up of scientific researches in this field.

Western scientists D. Bell, J. Galbraith, M. Castells, S. Kuznets, U. Rostow, R. Solow, A. Toffler, J. Schumpeter attracted their attention to mechanisms of problem solutions, which arise in terms of development of the new economy in the modernized society, its backgrounds, foundations of realization and directions of possible revolution, role of knowledge and technological factors in the modern economic growth ensuring.

Ukrainian and Russian scientists V. Bazilevich, D. Boginja, T. Bogolib, V. Vlasjuk, V. Geec, A. Gricenko, V. Dementev, V. Inozemcev, V. Polterovich, L. Fedulova research the basis of the new economy, its formation and functioning in terms of market transformation, development of regions of Ukraine.

Along with it there remain problematical questions of regions development in the context of structural crisis on the one hand, and development of knowledge economy, smart, sustainable and inclusive development on the other hand.

\section{European vector of economy development in Ukraine}

In 2014 Ukraine signed the European Union Association Agreement, so it should live under laws of the European Union; adhere to the best examples of development of country as a whole and regions in particular.

Strategy «Europe 2020» has 7 directions:

- Innovation Union to improve conditions and opportunities to finance researches and innovations in order to guarantee that innovative ideas will be used in goods and services production, which will promote the economic growth, new job creation;

- Movement of young people to strengthen effectiveness of educational systems and promotion of young people attraction to labour market;

- IT technologies development plan in Europe for accelerating of the extensive development of high-speed internet and enabling the participation in general commercial environment for private natural and legal persons; 
- Sensible use of resources in order to make the economic growth independent from resources, promote the transition to economy with low carbon content, increase the use of renewable energy sources, modernize the transport sector and ensure a rational use of renewable energy sources;

- Industrial policy directed to globalization for business environment improvement, in particular for small and medium-sized businesses, to support the development of powerful and stable industrial base for general globalization;

- Plan to develop new abilities and increase a number of jobs in order to modernize labour markets, provide people with opportunity to obtain new knowledge and skills so as to increase job opportunities; improve relation between demand and supply in labour markets, including labour mobility;

- European policy against poverty, so that social and territorial interaction would widely distributed throughout the territory, and achievements in the field of economic development and population employment help to decrease the level of poverty all over the EU (Europe 2020. Smart growth, 2013; The new European strategy «Europe 2020», 2010).

These directions are twisted with main directions of the Fourth Industrial Revolution. In the World Economic Forum in Davos in 2016 the Fourth Industrial Revolution was announced. Government of Germany stated that German people build the Industry 4.0, the USA said for some years that the Age of World Wide Web is coming. Chinese people claim: "where is crisis, there are opportunities" (The fourth scientific revolution, 2015).

Indeed, many Ukrainian scientists consider that in prevailing conditions Ukraine has a unique opportunity to overcome crisis in a worthy manner, while realizing the main directions of the Strategy «Europe 2020» and main directions of the Fourth Industrial Revolution. Fourth Industrial Revolution is conditioned by:

- Development of technologies of customer experience management.

- Transition from mass production of the same products to "mass customization" - it is a mass production of individual orders.

- Globalization is displayed by "glocalization", i.e. “Think global, act local”.

- Development of technologies of The Internet of Things (IT) - internet of things, even internet of everything.

- Opportunities of distance control of everything, including production.

- 3D Printing.

- Production returns home, i.e. development of automation and robotization grade advantages of labour resources cheapness.

- Smart objects. Smart devices. Smart sensors.

- Global standards compliance becoming a necessity and is needed even by local markets.
- Sustainable development and stable growth of everything: population, economy, science, technologies on the one hand and consistently growing problems of ecology on the other.

Every revolution, including industrial, opens up possibilities. Social revolutions create certain means of social mobility, and industrial revolutions lead real innovators to the front and open up possibilities. Correspondingly, Ukrainian engineers, IT specialists, entrepreneurs have new opportunities to develop new, advanced, progressive.

\section{Macroeconomic analysis of economy development in Ukraine}

Ukrainian economy and economy of regions are in conditions of structural crisis.

It is caused by variety of reasons: hybrid war in the east of the country, territorial loss of Ukraine, prolonged political crisis, battle of oligarchial clans for reallotment of land, enterprises, raw material resources, production distribution market.

As a consequence of it the fall of GDP in 2014 amounted to $7,6 \%$, in $2015-12,6 \%$; fall of industrial production in 2014 amounted to $24,6 \%$, in 2015 - 30,2\%; inflation over a period of 2014-2016 amounted to $350 \%$, growth of unemployment amounted to $40,2 \%$, foreign debt of Ukraine has grown up to $1 \mathrm{t} l n$. $500 \mathrm{bln}$. UAH (Key figures for the 2006-2016 financial condition (the first half), 2016). 5 million people leaved Ukraine; 30 thousand people were wounded during military operations; 13 thous. people died; 1,5 bln. out-migrants, which most often have no job, means of subsistence, accommodation; there are 300000 orphaned children in Ukraine (for comparison, there were 10 thous. people after the Great Patriotic War) (The main indicators of economic and social development of Ukraine 2015-2016 (first half), 2016). Increase in prices for foodstuff amounted to $300 \%$, for goods of first priority $-250 \%$, for medicines $-500 \%$, while income level grew by $26 \%$ (20\% in 2015 and 6\% in 2016), prices for gas grew by 7 times, for electric power - by 5 times, for public services - by 5 times (The main indicators of economic and social development of Ukraine 2015-2016 (first half), 2016). Consequently, differentiation of population life quality has sharply increased. The middle class is destroyed.

Ukraine has great losses in Donetsk and Luhansk regions. Budget of Ukraine in 2014 has received 23 bln. hryvnias less (about 1 bln. USA dollars), in 2015 - 28 bln. hryvnias (1,1 bln. USA dollars). Ukraine has lost 4 thousands enterprises in the Crimea, that amounts 1,18 tln. hryvnias. Reduction of objects of industrial production in Donetsk region in 2014 amounted to $31,5 \%$, in Luhansk region 42\%; correspondingly in 2015 in Donetsk region - 38,4\%, in Luhansk region - $47,5 \%$ (In the Donetsk region damaged and destroyed more than 10 thousand objects, 2015; For the restoration of Luhansk region will require more than UAH 3 billion, 2015). 
Traditional production links "coal-coke-metal", "coalelectric power" are broken in basic industries of Donetsk region.

Metallurgy production output amounts to $38,9 \%$ from the level of 2013, coke has fallen by $31,6 \%$. Export of metal production has fallen by 12,6 bln. USA dollars (The main indicators of economic and social development of Ukraine 2015- 2016 (first half), 2016).

Losses of national metallurgy enterprises are evaluated as $40 \mathrm{bln}$. hryvnias, where $25 \mathrm{bln}$. hryvnias are losses from non-manufactured goods (The main indicators of economic and social development of Ukraine 2015-2016 (first half), 2016).

Losses from destruction of capital assets are $15 \mathrm{bln}$. hryvnias (The main indicators of economic and social development of Ukraine 2015-2016 (first half), 2016).

Coal production has fallen by $35 \%$. Among 150 coal mines 115 are situated in the territory of Ukraine being beyond the control. Chemical industry has reduced output by $47,5 \%$. Production of ammonia, carbamide, nitric acid, ammonium nitrate are closed down (The main indicators of economic and social development of Ukraine 20152016 (first half), 2016).

Agricultural industry has received more than $3 \%$ of gross production of agricultural production less (7,5 bln. hryvnias) (Key figures for the 2006-2016 financial condition (the first half), 2016).

In Ukraine 1514 objects of railroad infrastructure are damaged, $1561 \mathrm{~km}$ of highways are destroyed. Donetsk and Luhansk airports are destroyed completely (The main indicators of economic and social development of Ukraine 2015-2016 (first half), 2016).

Macroeconomic instability, economic and political crisis have led to outward investment outflow and withdrawal of capital outwards Ukraine. 112 bln. USA dollars were got out from Ukraine over the period of 20142016 (Key figures for the 2006-2016 financial condition (the first half), 2016). All of that has an effect on the national economy state and development of regions. Economic crisis deepened a differentiation of regions. There are 24 regions in Ukraine, but only 7 of them are not depressive: Kyiv, Zaporizhzhia, Dnepropetrovsk, Kharkiv, Poltava, Lviv and Odesa regions. 17 regions are depressive by all macroeconomic indicators (The outflow of deposits, 2015). Kyiv is successfully developing, but city authorities have an external debt of $2 \mathrm{bln}$. USA dollars, city cannot return it and more than once was found on the verge of default (Bogolib, 2015).

Policy of the National Bank is imperfect. In the context of deep economic crisis the National Bank pursues a policy of flexible exchange rate, systematic refinancing of commercial banks, 82 banks are liquidated (The new Ukrainian five - year plan, 2010). Population has lost about $200 \mathrm{bln}$. of savings, $174 \mathrm{bln}$. hryvnias are taken away from banks by population (The outflow of deposits, 2015). Such a policy is insufficiently considered, evokes popular dissatisfaction, and harms all financial system of Ukraine.
Ukraine has declared implementation of an administrative-territorial reform with main staking on regions and communities creation, which supposes settlements unification. Directions of local governments' decentralization are declared. Decentralization is successful for developed regions, which are developing, have an industrial potential; for depressive regions decentralization is not a basis for development, conversely these regions without state budget's support are destined to further decay.

For Donbas revival, in accordance with experts, $15 \mathrm{bln}$. dollars are necessary. Donbas is an old-industrial region, where the main thing always was mining of coal and iron ore. It is a raw material region. Coal mines are mostly not modernized, primary metals establishments with the exception of integrated iron-and-steel works named after Ilyich and Azovstal are in 3 and 4 technological mode by their technological equipment, their revival and modernization need more than $20 \mathrm{bln}$. dollars (The main indicators of economic and social development of Ukraine 2015-2016 (first half), 2016). The situation is not simple, especially considering the lack of funds in the State Budget and direct foreign investment.

\section{New directions of region development in Ukraine}

We see a further development of Ukrainian regions in the implementation of main directions of the Strategy «Europe 2020» and main directions of the Fourth Industrial Revolution.

In speaking of the Fourth Industrial Revolution, famous economist, participant of Davos meeting Jennifer Blanke said: "If you think about the 3 rd Industrial Revolution, that was really computerisation - that was the digital age that started around mid-20th century. And what we're seeing is that the 4th Industrial Revolution is really building on that with all these exciting technologies, whether it's biotech, artificial intelligence, 3D printing - all of these different, exciting things that are coming together." (The Fourth Industrial Revolution, 2016).

Leading specialist of HIS Consulting Nariman Behravet thinks that poor reaction of Chinese officials to financial troubles is, maybe, a short-term risk for the world economy. Specialist considers that it will not lead us to recession, but investors are strongly nervous, and it influences on financial markets throughout the world (Davos-2016: the revolution of the future and the challenges of the present, 2016).

The World Economic Forum described the Fourth Industrial Revolution as a tsunami of technological innovations, which will be transforming our economy, but what an impact will it have on labour market, where will a job for all people come from, is still a question.

Ukraine has every prospect of success to be in the van of the Fourth Industrial Revolution.

In 1951 in Ukraine was created and put into operation the third in the world computer (after the USA and Great 
Britain), called SEAM (the Small Electronic Accounting Machine) (Davos-2016: the revolution of the future and the challenges of the present, 2016).

As of the beginning of 2016 the amount of computers in the world runs up to $2 \mathrm{bln}$. and continue to increase. The most computers are in the USA, Japan, Germany, Great Britain, Canada, France, Spain, Chinese, and Australia (Davos-2016: the revolution of the future and the challenges of the present, 2016).

History of the World Wide Web begins in 1968, when in the USA a military computer network Arpanet was started to develop. The name was created using abbreviation ARPA (Advanced Research Projects Agency) and "net". Next year the first four IMPs had started working - in the universities of Los Angeles, Santa Barbara, Salt Lake City and Stanford (The Fourth Scientific Revolution, 2015).

First users of Internet appear in the territory of Ukraine in Soviet times. In the same time there starts some support of Ukrainian part of Internet domain space - UA domain. On 1 December 1992 the UA domain was officially delegated to Ukraine. From this point it is conventional to consider the beginning of the history of Ukrainian segment of Internet (The Fourth Scientific Revolution, 2015).

Leading innovative world corporations make everything to accelerate a rush course of the world industry. The list of the most innovative companies is headed by Apple, Google, Tesla, and Microsoft.

Innovations completely change not only mode of people's life, but also their consciousness. Almost all industrial processes are automating; even automobiles are able to transport us without drivers.

Ukraine, after the USA and Russia, take the third place in the world by the level of IT specialists training.

Biotechnologies, nanotechnologies, and genetic engineering can become leading blanches in depressive regions of Ukraine.

In Ukraine a projects number is realized that can transform to depressive regions and territory of Donbas and in the future to ensure their successful development Smart City and Smart Home.

Smart City projects are implementing in Kyiv and Vinnytsia. They are directed to cities' development and are successfully introducing in megalopolises of the whole world.

In April, 2015 Kyiv joined to Smart City movement. The main purpose of this initiative is, joining efforts and attracting modern technologies, to make Kyiv developed and comfortable for life.

Under the Kyiv Smart City Project a several projects are carried out. First of all, an electronic budget of the city is run and now citizens and public authorities of the city can keep up with main indicators of city public funds distribution. Also banking card fare system is introduced and energy management system for Desnianskyi District is developed (Kyiv Smart City, 2015).

Smart City projects are implementing in many big cities throughout the world: London, New York, Paris, Helsinki, Berlin, Tokyo, Singapore and Vienna.
Innovation attracting gives an opportunity to create conditions for fast and qualitative solving of main problems of megalopolises. Thus, in Boston after the terrorism act a preventive system of security control was run. It allows scanning of everything - even social networks - and determining of security sources for citizens.

In 2015 Vinnytsia was included to the UNO Smart Cities Development Project.

Pilot project for "smart" cities net development includes Turaw in the Republic of Belarus, Vinnytsia in Ukraine, Goris in Armenia and Dushanbe in Tajikistan (Vinnitsa is included in the UN project for development of «smart» cities, 2015). The aim of the project is to prepare megalopolises and settlements for a set of problems arising in terms of urbanization.

In Ukraine in many regions are successfully implementing Smart Home projects that have qualitative support systems and operational multiroom, with which help all electric appliances of a building are functionally linked and which can be centrally controlled from display panel. Appliances can be attached to computer network, which allows controlling them via PC and having a remote network access to them via Internet. Owing to domiciliary informational technologies integration, all systems and equipment coordinate inter se functions performance by comparing programs and outer indicators.

To determine high tech features of accommodation the following terms are used: intelligent building, smarthouse, digital home

Main functions of the smart house:

- reliable and easy-to-use system of security and video control;

- automatic centralized lighting correction depending on time of day and people's moving around the house (especially important for those who rear children or nurse an elderly relative);

- household activities, which are heaped on person's shoulders, in the smart house are conforming with all house systems and performing by the most easy and effective way using modern equipment. It can be, for example, watering of a garden and its covering from the sun in accordance with weather conditions; doors opening for pets pasture so that in the morning they can go outside by themselves;

- gas and water control;

- energy-saving orientation;

- home automation of a house allows improving of living conditions and simplifying of domestic tasks for invalids;

- ability to control intellect and home appliances via interface using telephone directory, mobile communication or Internet;

- all functions are performing using one display panel;

- fully-featured home theatre;

- necessary facilities for games;

- creative technology can be effectively introduced into interior of house, office; 
- presence of necessary facilities and functioning of rooms is in accordance with child rearing: its development, safety and entertainment.

Smart houses as well as most of current technology achievements firstly appeared on pages of fantastic publications; this idea has materialized only in the XX century after wide spreading of electricity in buildings and development of informational technologies. Considering the macroeconomic state of regions, it is better to abandon the old and build new.

New economy researches from the point of view of Belkovskiy's triad "non-industrialism - industrialism post-industrialism" allows fixing of gradual strengthening of its role and forecasting of further growth of quantity and variety of its manifestations, increasing of specific weight of new economy in the context of accelerating of scientific and technological advance, constant update and modernization (Krainik, 2002). New phenomena include smart cities and smart houses. In terms of traditional society decay the value of post-industrial, service, informational, knowledge economy is growing and smart development becoming the main point.

Transition to the new Kondratiev wave indicates a gradual exhaustion of potential of modern version of the new economy, engine of future economy development will belong to other technologies and branches. Intensification of efforts to develop new technologies, generation of production competitiveness, which will be necessary in future markets, will become a basis for successful integration of Ukrainian economy into the world one, obtaining a status of powerful player in terms of the new economy, whereupon the role of regions will considerably increase. Regions will become a basis and initiators for development and introduction of new technologies, assimilation of new goods productions.

\section{Conclusions}

Modern stage of the world economy development is characterized by accelerated scientific and technological and social advance, formation of the new economy, smart, sustainable and inclusive development, where knowledge reproduction has a significant impact on the dynamics of economic growth.

Regional development plays an important role in economic development, strengthening of the role and significance of regions' development.

Regions in Ukraine have a big disbalance of development. Especially it concerns old industrial regional, including Donetsk and Luhansk regions, which are in the war zone.

All old is situated in 3 and 4 technological structures. To modernize branches is not easy, it needs money, but there is no money. Thus it will be more efficient to modernize new, successfully take part in the Fourth Industrial Revolution and begin to realize the Strategy "Europe 2020". New economy formation in Ukraine, which is based on knowledge, is related to qualitative changes in structure and development level of national economy complex, ensuring of regional development.

Society, which is based on knowledge, needs an elaboration of new ideology that run through the whole society and is oriented at innovations. Leading role in this process is assigned to interconnection of government, society, business and scientific society. In the long run it is a scientific-innovation sector of economy rather than fuel and raw materials sectors that will able to ensure the breakthrough of Ukraine into the innovative economy. Human intelligence is becoming the chief value of a new economy, and quality of labour will be characterized by capacity of an individual to generate new knowledge, ideas and discoveries.

Smart cities and smart houses will allow foreseeing of significant progress and establishing of socially fair way to apply labour and creative abilities of a human.

A basis for modernization would become a smart, sustainable, inclusive development.

In terms of crisis the state should not to dissipate financial resources, but to determine main regions, main branches, which will become priority on a long-term horizon, which will take into consideration the Strategy "Europe 2020", main directions of the Fourth Industrial Revolution; innovative development of social system; creation of education and rearing integrity, that all finally should ensure smart, sustainable, inclusive development of regions and the country as a whole.

\section{Reference:}

Bogolib, T.M. (2015). Disparities of regional development in Ukraine. European Cooperation in 2015, No. 7, p. 9-25.

Davos-2016: the revolution of the future and the challenges of the present. Retrieved from: http:/ru.evronews.com/ 2016/01/19/what-is-the-4th-industri-al-revolution.

Europe 2020. Smart growth. Retrieved from: http://rpp.nashaucheba.ru/does/index-44576.

For the restoration of Luhansk region will require more than UAH 3 billion. Retrieved from: http://telegraf.com.ua/ biznes/economika.

In the Donetsk region damaged and destroyed more than 10 thousand objects. Retrieved from: http://news.mail.ru/ inworld/ukraine/incident/21179530/?frommail=1.

Key figures for the 2006-2016 financial condition (the first half) years. Retrieved from: http:/minfin.gov.ua/ control/uk/publish.

Krainik, O.P. (2002). Economic development the region: monograph. Lviv: Liga-press, 294 p. 
Kyiv Smart City. Retrieved from: http://dreamkyiv.com/category/novini/kyiv-smart-sity. Peshkov, L. (2004). Ekonomichne zrostannya v Ukrayini: regionalnyj vymir: monografiya. Cherkasy, 272 p. The Fourth Industrial Revolution. Retrieved from: http://vol-foto.int.ua/pagsi/istomist/statti/2016rik/ dm160204.

The Fourth Scientific Revolution. Retrieved from: http://moyaosvitacom.ua/filosofija/chetverta-naukovarevolyuciya.

The main budget parameters - 2016. Retrieved from: http://minfin.gov.ua/control/uk/publish/article?art $\mathrm{id}=408887$

The main indicators of economic and social development of Ukraine 2015- 2016 (first half) years. Retrieved from: http://Minfin.gov.ua.

The new European strategy «Europe 2020». Retrieved from: http://eulaw.ru/content/.

The new Ukrainian five - year plan. Retrieved from: http://economics.lb.ua/state/2010/09/11/64675_novaya_ ukrainskaya.

The outflow of deposits. Retrieved from: http://news.mail.ru/inworld/ukraine/economics/21216177/.

Vinnitsa is included in the UN project for development of «smart» cities. Retrieved from: http://www.myvin.com.ua/ $\mathrm{ru} /$ news/events/32317.

\section{Таьяна БОГОЛИБ}

\section{ОБЕСПЕЧЕНИЕ УМНОГО, УСТОЙЧИВОГО, ИНКЛЮЗИВНОГО РАЗВИТИЯ РЕГИОНОВ УКРАИНЫ В УСЛОВИЯХ СТРУКТУРНОГО КРИЗИСА}

Аннотация. Формирование экономики, основанной на знаниях (инновационной экономики, новой экономики), на современном этапе общественного развития является определяющей международной концепцией, согласно которой знания играют первостепенную роль, а их производство является источником экономического роста и конкурентоспособности. Экономика, основанная на знаниях, обеспечивает умное, устойчивое и инклюзивное развитие. Цель исследования. Показать, что реализация Стратегии «Европа 2020», основных направлений Четвертой промышленной революции в Украине сможет обеспечить умное, устойчивое, инклюзивное развитие регионов Украины, поможет преодолеть кризис и станет источником экономического роста. Методы исследования. В процессе написания статьи были использованы общенаучные методы, методы анализа и синтеза, метод научной абстракции. Результаты исследования. Макроэкономическая нестабильность трансформировалась на региональный уровень, что привело к углублению дифференциации регионов, особенно это сказалось на старопромышленных регионах, в том числе Донецком и Луганском. Кризис государственных финансов не позволяет привлекать финансовые ресурсы для экономического развития. В результате гибридной войны отток внешних инвестиций составил 12,6 млрд. дол. США. Значительная часть Донецкой и Луганской областей разрушены полностью. Вместе с этим, это прекрасные условия для того, чтобы отказаться от старого и начать строить новое. Есть все условия, чтобы активно реализовать европейскую стратегию «Европа 2020» и основное направления Четвертой промышленной революции, выйти на новый этап экономического развития и обеспечить умное, устойчивое и инклюзивное развитие регионов Украины. Выводы и дискуссионные положения. Будущее Украины, ее регионов зависит от активности реализации Стратегии «Европа 2020» и основных направлений Четвертой промышленной революции. В Украине, в регионах основная ставка делалась на экспортоориентированные отрасли:угольную, металлургическую, химическую, машиностроительную промышленности. Технологически они находятся в 3 и 4 технологических укладах, поэтому они не могут стать прорывными отраслями украинской экономики, поэтому основная ставка должна быть сделана на умное, устойчивое и инклюзивное развитие. 